\title{
Making a Lecture Course Student Centered: Steps and Issues
}

\section{Amanda Gillis-Furutaka \\ Kyoto Sangyo University}

\section{Reference Data:}

Gillis-Furutaka, A. (2020). Making a lecture course student centered: Steps and issues. In P. Clements, A. Krause, \& R. Gentry (Eds.), Teacher efficacy, learner agency. Tokyo: JALT. https://doi.org/10.37546/JALTPCP2019-39

The purpose of this paper is to describe the process of changing the delivery style of a teacher-led, English-medium university lecture course (Culture and Literature of English-Speaking Areas) into a student-centered, active-learning course. This process began as a collaborative action research project (Burns, 1999, 2009a). In this paper, the original course and the reasons for making changes are discussed, and then the measures taken to make the course student-centered are presented and examined. These measures include the addition of pre-class activities, such as the viewing of video recordings of short lectures, that are subsequently used in a wide range of in-class activities. The underpinning theory supporting the changes introduced is derived from findings in the fields of educational psychology and neuroscience. Finally, student feedback regarding outcomes and ongoing issues, such as in-class and out-of-class study and the composition of groups for in-class activities, is summarized and evaluated.

本稿では、教師主導の英語を媒介とする大学の講義(英語圈の文化と文学)を、コンテンツに基づき受講生中心のアクテイ ブラーニングコースに変更した過程について説明する。このプロセスは、共同アクシシンリサーチプロジェクト (Burns， 1999, 2009a)の一環として始まった。最初に、元々゙のようなな受業内容だったのかと変更が必要だった理由について述べる。次に、

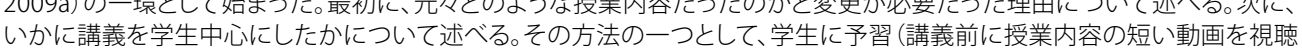

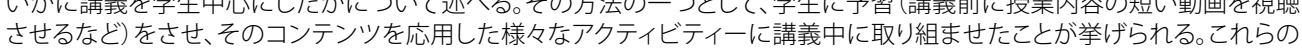
変更に至つた理論は、教育心理学および神経科学に裹付けられている。最俊に、学生によるこの授業の評便と学生の著しい成 績向上なと改善が見られた点授業外で求められる講師の役割と受講最の予習なと王現在直面している問題について触れる。 n 2014, I started teaching a one-semester lecture course called Culture and Literature of English-Speaking Areas focusing on the music of the Beatles. This elective Englishmedium 2-credit content course is open to students starting in their third semester. The number of students enrolled has varied between 39 and 85 . The majority are 2nd-year students, but 3rd-year and 4th-year students also enroll.

The purpose of this paper is to describe the course content, delivery, and evaluation system from 2014-2016 and to identify reasons for my dissatisfaction with outcomes. I then explain steps taken from 2017-2019 to change the course from a mainly teacherled information-transfer approach to a student-centered active-learning approach. This process was undertaken as a collaborative action research project. The aims of this paper are (a) to explain why active and cooperative learning are effective from the perspective of psychology and neuroscience, (b) to outline and evaluate the changes made, and (c) to highlight issues that still need to be addressed.

\section{Original Course (2014-2016) and Reasons for Change Course Content}

The aim of the course is to enable students to appreciate the influence of the Beatles on popular culture by familiarizing students with the creative work of the Beatles (their music, films, and promotion film clips).

\section{Course Structure}

Each lesson began with a 15-minute multiple-choice review quiz. Students were expected to reread the class handouts and PowerPoint slides available on Moodle, an online learning management system. Latecomers had less time for the quiz and absentees received zero for the quiz score that week. The quizzes accounted for $50 \%$ of the course grade. 
The lesson contents were delivered through short lectures in English, supported with PowerPoint slides and handouts. Because the human attention span is generally 10-20 minutes (Medina, 2014), the lectures were kept to around 15 minutes and followed up with review activities such as (a) finding and correcting mistakes in a summary, (b) filling in missing words/phrases in a summary, (c) ordering the events covered, and (d) matching sentence halves to create a summary. The students also discussed questions based on the lecture.

Video clips were used between the lecture segments of the lesson. These included song lyric videos, clips from television and live shows, and promotion clips. Clips from the films that the Beatles made were also used, and short reading passages were adapted from academic studies of the Beatles and their music.

The remaining $50 \%$ of each student's evaluation was based on a 700 -word report on one of 14 different weekly topics. The report could be submitted at any time during the semester.

\section{Reasons Why the Course Delivery and Evaluation System Were} Ineffective

It became increasingly clear that both the delivery of the course content and the evaluation system were unsatisfactory. First, although the quizzes encouraged the students to arrive on time, few reviewed the lesson contents sufficiently to score well, and this impacted their overall grade. Second, although the students reported enjoying listening to the Beatles' music in their course feedback, many found these segments of the lesson so relaxing that they fell asleep. This defeated the purpose of familiarizing them with the evolving styles of the Beatles' music. Third, the only part of the course that they focused on in depth was the topic they chose to research and write about in their report. I therefore decided to change my teaching approach and evaluation system.

\section{Collaborative Action Research}

At the JALT2016 international conference, Professor Anne Burns explained action research and challenged the audience to identify a course that needed changes. Action research is carried out by teachers in their own classrooms. It involves acknowledging problems, trialing interventions, evaluating their effectiveness, and making appropriate changes (Burns, 1999, 2009b). A friend and I were eager to change a course and agreed to collaborate on two action research projects. Our collaboration consisted of observing each other's classes, discussing changes that were needed, and exchanging suggestions about how to implement these changes. We reported to each other about the changes we were making and provided feedback.

This experience demonstrated to me many advantages of working collaboratively. Although it may feel uncomfortable to have another teacher present in one's classroom or view a video recording of a lesson, the quality of advice the collaborator can provide is worth this discomfort because their view combines the perspectives of a class participant and a fellow professional. Moreover, when class observation is carried out mutually, each observer is mindful that they will also be observed and is therefore motivated to offer constructive advice.

\section{Research Questions and Preparation}

The research questions were:

RQ1. How can lecture course content be delivered in a student-centered way?

RQ2. How can the students' active involvement be achieved during each lesson?

RQ3. How can each homework assignment be made meaningful and related to classwork in the following lesson?

RQ4. Can the evaluation process be transparent and include individual and group classwork plus out-of-class work?

Permission was requested from my university's Research Ethics Committee to survey the students at the start and end of the course, to video record and photograph students and student work in class, and to make copies of their written assignments. The research project was explained to the students, and they were asked to sign consent forms at the start of each semester (see Appendix A).

To address the research questions, findings in the fields of psychology and neuroscience and their application to the classroom were consulted. They have provided the theoretical basis for the changes in teaching and evaluation methods that have been implemented and are outlined below.

Active Learning and the Roles of Attention, Emotion, and Student Collaboration

Active learning is being introduced in schools and universities overseas and by the Japanese Ministry of Education, Culture, Sports, Science, and Technology (MEXT; Johnson \& Johnson, 2008; MEXT, 2020). Accordingly, my university requires all syllabi to reflect this approach by including key words such as group work, discussion, and 
presentation. To be effective, however, active learning involves more than participating in group discussions and presentations; it requires collaboration and individual accountability. Moreover, students need to learn how to work successfully in groups and take responsibility for their own learning, and teachers need to establish means of measuring the level of individual accountability of their students (McMurray, 2018). MEXT defines active learning at the tertiary level as "learning in which students proactively find issues and solutions" and recommends the promotion of activities such as "interactive lectures, practice, and experiments" (MEXT, 2020, Basic Measure 8). Furthermore, MEXT recommends "an increase and guarantee of the total proactive student study hours, including preparation before classes and deployment after" (MEXT 2020, Basic Measure 8). Implementing such measures requires changes in the delivery of course material and assessment of student learning and in student willingness to participate actively in the learning process.

The active-learning approach recognizes that learning takes place only when students are motivated and engage directly with the material to be understood. Such studentcentered learning is fundamentally different from memorization of information provided by an instructor. The active-learning approach requires the instructor to provide stimulating course material and maintain student interest so that students invest time and energy in interacting with it and in committing essential aspects to memory.

Active learning means getting students involved in activities during lessons and not simply listening passively (Cavanagh, 2019). Students need to do something if they are going to learn. For example, when listening to information in the form of a lecture, students need reasons to listen attentively. Teachers can create such reasons by setting up prelistening activities, such as discussions on the topic of the lecture that the students are about to hear, as well as activities during and after the lecture.

Student engagement in an activity requires emotional involvement (Cavanagh, 2019). Cozolino (2013) clarified the importance of emotion and personal relevance in learning: "We learn through emotional engagement in our educational experience-finding what is relevant to our personal lives, and what in our personal lives can be relevant to what we are learning" (p. xiii). Emotions drive human decision-making and subsequent learning by stimulating attention and working memory (Tokuhama-Espinosa, 2011). Medina (2014) explained: "The more attention the brain pays to a given stimulus, the more elaborately the information will be encoded-that is, learned-and retained" (p. 106). First, attention has to be harnessed and this is achieved most effectively through new and unexpected stimuli-the more unusual, unpredictable, or distinctive, the better (Medina, 2014). Emotionally charged events (frightening, funny, or surprising) are remembered longer and with greater accuracy than neutral events. This is because they stimulate the amygdala (a part of the brain that helps to create and maintain emotions) to release the neurotransmitter dopamine into one's system. Dopamine helps one process information and commit it to memory. Whereas it used to be thought that emotions disrupt and impede understanding, neuroscience is revealing that "the most efficient and effective learning incorporates emotion into the cognitive knowledge being built" (ImmordinoYang \& Faeth, 2010, p. 76). Moreover, if students feel no personal emotional connection to the information they study in the classroom, the academic content will be emotionally meaningless to them; even if they are able to reproduce the facts on a test, this will not influence their future decisions or behavior (Immordino-Yang \& Faeth, 2010).

Emotion is also involved in consolidating learning because deep understanding requires students to make emotional connections between concepts (Immordino-Yang \& Damasio, 2016). In fact, it is "neurobiologically impossible to build memories, engage complex thoughts, or make meaningful decisions without emotion" (Immordino-Yang \& Damasio, 2016, p. 18). In other words, we think deeply about the things we care about. Teachers need to help students perceive connections that are exciting and deeply meaningful to them and which will lead to "the development of truly useful, transferable, intrinsically motivated learning” (Immordino-Yang \& Damasio, 2016, p. 20).

\section{Four Ways to Engage Students}

1. Recognize Cognitive Resource Limitations

Human cognitive resources, such as attention and working memory, are limited (Cavanagh, 2019), so teachers need to be mindful that students face several related demands when presented with new material. They have to understand both the new material and the instructions for a task when working with this new material. They then need to perform the task successfully in order to learn from it while also coping with distractions, such as noisy classmates or buzzing phones.

To reduce the cognitive load for students, break the lesson into 15- to 30-minute segments, each with a different activity related to the overall aim of the lesson. Every activity should be relevant to the emotional lives of the students. Another way to refocus attention is to vary class routines. Variety is a vital ingredient for an engaging lesson.

\section{Help Students Fall in Love With the Subject Matter}

Teachers can engage students by demonstrating their own passion for the course contents. Research into emotional contagion has demonstrated that emotions and 
moods can easily spread among a social group, such as a university class. The enthusiasm of instructors can therefore influence the motivation and level of effort that students invest in their class (Cavanagh, 2019). Watching a video recording of yourself teaching can be a very useful way to measure your enthusiasm.

\section{Establish a Sense of Community}

Remember that homo sapiens have the extraordinary ability to share attention with others and to learn from and teach others (Dehaene, 2020). Use the cooperative and social nature of human beings (Cozolino, 2013) to establish a learning community in the class so that students will feel relaxed, will be willing to participate in discussions, and will try hard on all assignments on individual, group, and class levels.

\section{Use Narratives}

Human thought naturally takes the form of stories (Beach, Bissell, \& Wise, 2016). Narratives link together isolated pieces of information to create a meaningful whole. Student engagement, comprehension, and memorization can be enhanced through the use of the causal relations in stories (Willis, 2017). Moreover, narrative structure enables us to summarize the stages of a story, reducing the burden on working memory and facilitating connections with long-term memory. Thus, stories facilitate learning because they are easily understood and recalled and because they enable us to make connections between new information and what is already known. When delivering information, frame it as a story, include personal anecdotes, and encourage students to do the same.

\section{Active Learning as Cooperative Learning}

Cooperative learning uses small groups and shared responsibility to encourage students to participate actively in lessons to achieve a set of goals for a successful outcome. Students also retain more and have more positive feelings towards the subject matter and to their own academic achievement than in individualistic and competitive learning situations (Johnson \& Johnson, 2008). According to social interdependence theory (Johnson \& Johnson, 2005), five conditions are essential for effective group cooperation. First, all group members should understand that they and their actions are interconnected and that they can only succeed if each member of the group is also successful. This is called positive interdependence. The second condition, individual accountability, is awareness that each group member is responsible for contributing a fair share of work. Third is promotive interaction, which involves encouraging and helping each other to succeed. Fourth is a set of skills such as interpersonal skills that facilitate communication, trust, decision making, and conflict resolution. For the final condition, group processing, group members reflect on how well they are working cooperatively and how they could improve their collaboration.

The instructor's role is vital to the success of cooperative learning and involves the following responsibilities: assigning students to groups, designing the tasks, providing clear instructions, monitoring the groups, providing clear and fair evaluation criteria, and allowing the students to reflect on and assess their teamwork. Groups can work more effectively when they are small (2-4 people) and heterogeneous so that they can share their different levels of expertise, knowledge, and skills. Tasks should have a clear goal and require the input of all team members to be accomplished. The goal should be a product (e.g., a poster or presentation) that all members can put their name to.

\section{Six Innovations}

Informed by the recommendations outlined above, six changes were made to encourage students to participate actively in class.

1. Homework content is always used in the next lesson; students need to do the homework to participate actively and to complete the in-class assignment(s) successfully.

2. Homework and class activities vary each week and involve personal responses to the course content.

3. Students work in small groups and the groups change every 3 weeks. Group composition is assigned by the teacher, except for the final presentation (on the Beatle of their choice) for which the groups self-select. The groups are mixed so that students in their $2 \mathrm{nd}$, 3rd, and 4 th years can work together.

4. Students produce a piece of work in or before class each week for evaluation. This can be an individual response to the topic, in written or spoken form (i.e., handwritten, word processed, or recorded on their phone and uploaded to Moodle), or group work in the form of poster presentations, opinion polls, or class questionand-answer activities.

5. Students research and make a group PowerPoint presentation on the career of one of the Beatles after 1970. The presentations are evaluated by the whole class using evaluation sheets with a simple rubric.

6. Each student produces an academic-style 700-word report based on their group's presentation, which is read and evaluated by the teacher. This assignment ensures 
that students who do not perform well when speaking English in front of an audience have an opportunity to express their ideas in writing. The teacher provides a grade and feedback to each student individually.

\section{Examples of Homework and Class Activities \\ Week 1 Homework}

1. Follow-up reading based on the content of the lesson about the 1950 s music scene in the UK when the Beatles were teenagers.

2. Listening to two or three songs of their own choice by each of the eight different artists listed who inspired the teenage Beatles. Students note the song titles, the instruments, the tempo, rhythm, and performance styles of the artists. Which did they like or dislike and why? They should be ready to share their opinions with other students and write a short assignment about these artists in the next lesson.

\section{Week 2 Lesson}

1. Group discussion on the music they listened to, sharing suggestions, and listening to music suggested by others (20 minutes).

2. Individual writing assignment (20 minutes). Topic: "The music of the 1950 s that inspired the Beatles." This is graded by the teacher with comments and suggestions and returned during the next lesson.

\section{Week 4 Homework}

Students listen to the album Help! and answer the following questions. They bring their answers to the next lesson.

1. For the first time on a Beatles album, two tracks written by George Harrison were included. Are his songs similar to or different from those written by John Lennon and Paul McCartney? Explain why or why not.

2. What are your favourite tracks on this album? Explain why you like these songs (e.g. lyrics, melody, rhythm, arrangement and instruments used, voices, mood, etc.)

Week 5 Lesson

After exchanging their opinions about the album Help!, each group makes a poster about the album. The students take turns giving and evaluating the poster presentations using an evaluation sheet with a simple rubric. The scores from the evaluations for each group are announced in the next lesson.

\section{Video Lectures}

In 2017, my research collaborator observed that a lot of class time was spent lecturing and suggested delivering the lectures by video for homework. In collaboration with the Media and Communications department, seven short (10 to 15 minutes) video lectures were made in 2018 and 2019. In the videos, I talk to the camera accompanied by PowerPoint slides, which are visible beside me. The videos are posted on Moodle with a YouTube link, and there are various kinds of follow-up activities to prepare for the next lesson. Some of the activities require responses that are written and uploaded to Moodle; others require the students to prepare for discussion topics in the next lesson by making their own notes. The students' evaluation of these videos can be seen from the survey responses below.

\section{Student Feedback on Video Lectures}

Bad Points:

- English is difficult-"please add Japanese translations."

- "Difficult for students who don't have any smartphone or PC."

"I don't like that."

\section{Good Points:}

- "Students can watch everywhere if they have a smartphone."

- "Students can watch it whenever they are free."

- "We can focus on the homework more deeply."

- "I could find the answers by listening to your lecture again and again."/"I watched this video 3 times to solve the homework questions."

- "Students can't stop and repeat a lecture that is given in class."

- "I can see the speaker and PowerPoint clearly so I can understand easily."

In response to the bad points, the request for subtitles shows lack of appreciation that an English-medium course provides students with opportunities to work on their 
English skills in addition to studying the content. Second, although there may be some students who do not have a smartphone or computer, there are plenty of computers available on campus if they plan their work accordingly. The final point underscores the fact that not all students like the same kinds of activity so variety is important. The video lectures therefore comprise only $50 \%$ of the homework assignments.

\section{Reflections on Course Feedback}

At the end of the semester, students fill out an optional feedback survey. In 2019, 27 students responded. For their responses, see Appendix B.

It is striking that the students did not view the in-class activities as an integral part of learning the course contents. They commented only on the teacher's explanations in lessons and video lectures as if these were the only times they thought they were learning the course contents. They did not see discussions with classmates and the work they produced as part of the learning process. For example, the comment "I thought we were going to learn the meaning of lyrics deeply" suggests that this student expected to be told what the songs meant rather than to be invited to think about this for themself.

To verify this interpretation of student expectations, further research using focus group discussions will be conducted next year. In addition, explanations will be included at the start of the course about how class activities are part of the learning process and how students can learn from each other and not just from the teacher.

Although opinions were split on the issue of whether the homework load was too great, by the end of the course, many students understood that the homework served a meaningful purpose. This message clearly needs to be repeated regularly throughout the semester. Nevertheless, weekly homework is also a burden and the request for a break should be respected.

To increase transparency about this issue and to measure the actual workload, when assigning the homework, the estimated length of time that the homework should take will be included, and students will be invited to report how much time they actually spent. This information will help measure the workload and plan for the assignments to be lighter some weeks than others.

There is a serious need to rethink the strategy for grouping students because the older students, instead of taking the lead by showing responsibility and doing the homework, were often the ones not doing the homework and so not contributing to group work. The following measures will be taken: (a) assign only one 4th-year student to each group, (b) include opportunities for groups to reflect and report on their collaborative efforts, and (c) explain to each of the 3rd- and 4th-year students that doing the homework each week is essential. Learning is a shared responsibility in this course; they should lead the 2nd-year students by their good example.

\section{Conclusion}

Making this lecture course student centered is a work in progress. It has generated new research questions and highlighted issues that educators face when implementing active learning.

The first issue to address is the students' expectations. Teachers need to explain the importance of class preparation so that the students do not expect to simply listen but are prepared to participate actively in class and learn through doing the assigned tasks. Next, teachers need to explain that their role is to facilitate the students' understanding of the course content by assigning activities in which every student will participate.

Active learning for students requires active teaching by teachers: planning lessons and homework so that students can relate to every assignment in a meaningful way, creating groups and troubleshooting when group interaction does not go as planned, providing feedback that guides and encourages students when needed, and praising them when they have worked well.

Evaluation should be transparent so that students can understand how they are expected to perform in the course and how well they are meeting those expectations. Extra attention and time are required, but the satisfaction of seeing the quality of the students' work improve provides compensation. In an English-medium lecture course, where students have different language levels and academic experience, evaluation should take various forms in order to be fair to all. It should include spoken work as well as written work, creative work as well as fact-based work, and individual work as well as group work. Moreover, grades should be based on the quality of the content and not on language level.

These practices are in line with the expectations of MEXT and are supported by findings in the field of education research based on psychology and neuroscience. My goals are to develop efficient and collaborative learners and to kindle their interest in the course content so that it becomes part of their lives well beyond graduation. 


\section{Bio Data}

Amanda Gillis-Furutaka is a professor in the English Department at Kyoto Sangyo University and Program Chair of the JALT BRAIN SIG. Her current research focuses on ways to use findings in psychology and neuroscience research to inform foreign language learners and improve language and intercultural education.

\section{Acknowledgments}

I would like to thank my action research collaborator, Gretchen Clark, who came to observe this class multiple times during the spring semester of 2017. She provided many very useful observations and recommendations without which I would not have transformed this course to the extent I did. I would also like to thank Professors Kohei Tahata and Malte Jaspersen and the students of the Media Communications department for their collaboration in the making of the seven video lectures for this course. Their professionalism and enthusiasm were inspirational.

\section{References}

Beach, L. R., Bissell, B. L., \& Wise, J. A. (2016). A new theory of mind: The theory of narrative thought. Newcastle upon Tyne, England: Cambridge Scholars.

Burns, A. (1999). Collaborative action research for English language teachers. Cambridge, England: Cambridge University Press.

Burns, A. (2009a). Action research in second language teacher education. In A. Burns \& J. C. Richards (Eds.), The Cambridge guide to research in language teaching and learning (pp. 289-297). Cambridge, England: Cambridge University Press.

Burns, A. (2009b). Doing action research in English language teaching: A guide for practitioners. New York, NY: Routledge.

Cavanagh, S. R. (2019, March 11). How to make your teaching more engaging. The Chronicle of Higher Education. Retrieved from https://www.chronicle.com/interactives/advice-teaching

Cozolino, L. (2013). The social neuroscience of education. New York, NY: W. W. Norton.

Dehaene, S. (2020). How we learn: Why brains learn better than any machine ... for now. New York, NY: Viking.

Immordino-Yang, M. H., \& Damasio, A. (2016). Emotions, learning, and the brain: Exploring the educational implications of affective neuroscience. New York, NY: W. W. Norton.

Immordino-Yang, M. H., \& Faeth, M. (2010). The role of emotion and skilled intuition in learning. In D. A. Sousa (Ed.), Mind, brain, and education: Neuroscience implications for the classroom. Bloomington, IN: Solution Tree Press.
Johnson, D. W., \& Johnson, R. T. (2005). New developments in social interdependence theory. Psychology Monographs, 131, No. 4. https://doi.org/10.3200/MONO.131.4.285-358

Johnson, R. T., \& Johnson, D. W. (2008). Active learning: Cooperation in the classroom. The Annual Report of Educational Psychology in Japan, 47, 29-30. https://doi.org/10.5926/arepj1962.47.0_29

McMurray, D. (2018). MEXT's new course of study guidelines to rely on active learning. The Language Teacher, 42(3). https://doi.org/10.37546/JALTTLT42.3

Medina, J. (2014). Brain rules: Twelve principles for surviving and thriving at work, home, and school. Seattle, WA: Pear Press.

MEXT. (2020). Measures based on the four basic policy directions: Basic measure 1: Improvement of educational content and methods to cultivate solid academic abilities. Retrieved from https://www. mext.go.jp/en/policy/education/lawandplan/title01/detail01/sdetail01/1373805.htm

Tokuhama-Espinosa, T. (2011). Mind, brain, and education science: A comprehensive guide to the new brain-based teaching. New York, NY: W. W. Norton.

Willis, J. (2017, September 12). The neuroscience of narrative and memory. Edutopia: George Lucas Educational Foundation. Retrieved from https://www.edutopia.org/article/neurosciencenarrative-and-memory

Appendix A

Student Consent Form

\section{研究への参加同意書}

研究概要(研究目的、必要性)

本研究は受講生達が講義に積極的に参加する手法を研究することを目的にしている。アクティブン 一ニングに必要なのは受講生に講義前に入念に下調べをさせることと、講義中は彼らが中心に課 題に取り組むことである。受講生たちの活動具合を測るため、申請者は講義の様子を動画撮影し、 筆記課題を分析するため、その筆記課題のコピーを取る。課程の終盤に受講生たちに今の授業形 式について評価する内容のアンケートをとる。

グループで行われる課題や議論の動画をとる。ポスターやパワーポイントを使ったプレゼンの作 成。被験者の筆記課題をコピー。教え方や授業形式に関する評価を課程終盤に被験者に実施。

研究に際して被験者(受講者)たちの活動を動画撮影し、筆記課題のコピーを取るが、動画から 被験者の個人情報は連結しない状態で保管する。筆記課題については、名前の部分を除いてコヒ 一する為、筆記課題のコピーと被験者の個人情報とは連結しない。また、課程終盤に行われるアン ケートは匿名で収集する。 
申請者自ら被験者たちの個人情報を集めるが、それは分析のためだけであり、個人情報は公表さ れない。

得たデー夕は全て申請者の研究室内の鍵のかかる保管庫で保管される。分析結果等はPC上で管 理するが、そのPCは申請者の研究室内で保管され、持ち歩きはしない。

研究期間終了後、収集したデー夕等は、適切に廃裹する。

本研究への参加希望者を募って、希望者には研究の詳細を説明し、同意書を取る。

受講者の本研究への参加は任意であり、参加しないことを希望したり、途中で辞退しても何も不 利益なことはない(同意書に記載)。集められた個人情報は第3者に無断で渡されることはない。

講義風景の動画撮影、筆記課題のコピー及びアンケート収集のため、被験者の負担及び予測され る危険性については、特にないものと考える。

私はアマンダ・ギリス・フルタカの研究に参加することを希望しました。私は授業中にビデオ録画さ れることに同意します。また、私の発言は研究者がそれを授業の記録としての夕使用することに同 意します。その上、私は自分が書いた文書が研究データのためにコピーされることに同意します。私 は自分の個人名が発表されないことを了解しています。さらにまた私はいつでもこの同意書を取り 下げられること、並びに本研究への参加/不参加が私自身の成績に何ら影響するものではない、と いうことを了解しています。

名前

平成年月日

\section{Appendix B}

Student Responses ( $\mathrm{N}=27$ ) to the 2019 Course Feedback Survey

1. Reasons for taking the course (some students gave more than one reason):

- Interested in the Beatles (11)

- Interested in (British) music (5)

To get credits (5)

- Interested in British/foreign culture (4)

- Interested in course contents (4)

- My friends were taking it (1)
- Taught in English (1)

- Interested in your English Studies class (1)

2. Was the course different from what you had expected? Explain why or why not.

- Yes (5) No (11) Neither yes nor no (11)

Some representative responses:

- "No, it wasn't because before the class I read the syllabus."

- "It was as I imagined because I could know many Beatles songs."

- "I knew only the famous band name "The Beatles" but after I almost finished this class, I understand them."

- "It was a little different because I thought we were going to learn the meaning of lyrics deeply."

- "I thought we were going to learn about other artists too."

- "It was more interesting than I expected because we can learn details of the Beatles."

- "I expected I can learn American culture."

- "This course fun and I could know a lot of the Beatles. However, homework was more than I expected."

3. Were the lessons easy to understand? Why or why not?

- Yes (18) No (6) Sometimes (1) No answer (2)

Some representative responses:

- "No, because you told deeply."

- "No, ...it was little bit difficult to understand English sometimes."

- "Difficult a little. All English"

" "Sometimes, lessons were difficult because I don't know any information about Beatles at first."

- "Homeworks were difficult."

- "No ... because I'm not good at English, but homework help me to understand."

- "Your English is easy to listen." 
- "Yes, ... because you explained in detail."

- "Yes, ... because we learned about Beatles by watching movies or listening music, so it was easy for me to understand."

- "It was very interesting, and nice to listen.

- "Yes, ...speaking speed and slides helps me to understand easily."

- "Yes, because the PowerPoint slides were really clear and there were a lot of videos and pictures to help us understand."

- "Yes ... because teacher uploaded some videos for assignment and explained to us very clearly in class."

- "It was easy to understand because before the lesson, l'd already learnt as homework."

4. Was there too much or not enough homework? Explain your opinion.

- Just right (3) Enough (8) Too much (14) Not enough (1) No answer (1)

Some representative responses:

- "Little too much because it takes a lot of time to understand the video lecture."

- "...a little bit a lot, but all of the homework was really helpful to understand the contents of the lecture."

- “...sometimes I want to take a rest."

- "I think too much at first, but it make me grow."

- "At first I thought it was too much homework, but I got used to be it and I did it!"

- "Too much but it was just good of contents."

- "I think it's a bit much for me, however they have challenging and also not boring.

\section{Were the mini lectures on Moodle useful?}

- Yes (24) No (1) No answer (2)
6. Are you satisfied with the course content, evaluation process, and what you were able to learn?

- Satisfied (22) No answer (5)

Some representative responses:

- "Amanda always evaluated our homework and activity on points...."

- "I'm satisfied with this contents and evaluation process. I was able to learn about more the Beatles and fun of learning about music."

- "Not only things about Beatles, I also learnt about British culture."

- "Yes. What I could learn in this class is expressing my feeling and impression."

7. Do you have any suggestions for improvements to the course?

Some representative responses:

- "I was able to know homework is important."

- "Teacher insisted to do homeworks again and again, however many students seemed not to .... It was sad because I couldn't discuss contents of homework actively in class. I think it was not teacher's fault."

- "There are some students who are 3rd or 4th years, and some of them did not do homework. So I don't like to do group activity with them. It is because I couldn't discuss with them, it wasn't group work."

- "I didn't like discussing with 3rd and 4th year students who didn't do homework."

- "I just say that it is more helpful for us to take a break from homework sometimes."

- "The course was great, and I am completely happy to take this course. On the other hand, my biggest concern was homework and lecture. I tried making a lot of efforts on doing homework in order to understand more the lecture. However, it made me stayed awake at night, I could not get up early, and I sometimes could not come to the lesson. That was bad routine, and I hope to had had less homework to finish." 